Экономика и управление. - 2012. - №5. - С. 6065.

7. Крикавський Є. В. Сучасна логістика потребує інновацій [Електронний ресурс] / Є. В. Крикавський. - Режим доступу: http://essuir.sumdu.edu.ua/bitstream/

123456789/28173/1/logist.pdf. - Назва з екрану.

8. Транспортно-логістична

інфраструктура України: проблеми та перспективи розвитку/ І. Г. Лебідь, В. В. Кутирєв // Управління проектами, системний аналіз і логістика. - К. : НТУ, 2012. Вип. 10. С. 192-198.

9. Сыздыкбаева Б. У. Методология формирования и развития интегрированной транспортно-логистической системы Казахстана : автореф. дис. на соискание науч. степени докт. экон. наук : спец. 08. 00. 05 Экономика и управление народным хозяйством (по отраслям и сферам деятельности) [Электронный ресурс] / Бакыт Узакбаевна Сыздыкбаева. - Туркестан, 2010. - Режим доступа: http://dislib.ru/ekonomika/24633-1-metodologiyaformirovaniya-razvitiya-integrirovannoytransportno-logisticheskoy-sistemi-kazahstana.php. Загл. с экрана.

10. Сирийчик Т. Транспортна політика України та її наближення до норм Європейського Союзу [Електронний ресурс] / Т. Сирийчик та ін. ; за ред. Марчіна Свєнчіцкі. - К. : Аналіт.-дорадч. центр Блакитної стрічки, 2010. - 102 с. - Режим доступу:

http://www.undp.org.ua/files/en_76033Transport_Sy stem_Reform_Jun2010.pdf. - Назва з екрану.

11. Соколова О. Є. Теоретикометодологічніі основи формування транспортнологістичної системи України [Електронний pecypc] / О. Є. Соколова. - Режим доступу:
http://ecobio.nau.edu.ua/index.php/PPEI/article/view file/182/173. - Назва з екрану.

12. Транспортная система США [Электронный ресурс] / Amerikos.com. - Режим доступа: http://amerikos.com/usa/transportation-s/. - Загл. с экрана.

13. Записка секретариата Европейской экономической комиссия об изменениях на транспорте в Европейском союзе [Электронный ресурс] / ООН ; ЭСС ; ЕЭК ; семьдесят шестая сессия, пункт 17. - Женева - 2014. - С. 2-4. Режим доступа к журналу: http://www.unece.org/fileadmin/DAM/trans/doc/201 4/itc/ECE-TRANS-2014-29r.pdf . - Загл. с экрана.

14. Роль глобализации экономики в развитии логистических систем [Электронный pecypc] / Режим доступа: http://serpavlion.narod.ru/K4/logistics/Tema_12_Globalnye_1 ogisticheskie_sistemy.htm. - Загл. с экрана.

15. Грузоперевозки в Европе: эффективность и равные условия для всех [Электронный pecypc] / Автотранспортный портал. - Режим доступа: http://transler.ru/content/arxiv_perevozhic/perevozhi c_08/perevozhic_99/Opyt_kolleg_quotGruzoperevoz kí_v_Evrope_effektivnost_i_ravnye_usloviya_dlya vsehquot . - Загл. с экрана.

16. Статистична інформація [Електронний ресурс] / Державна служба статистики України. - Режим доступу: http://www.ukrstat.gov.ua. - Загл. с экрана.

17. В Украине разработали транспортную стратегию до 2020 года [Электронный ресурс] / ЛІГАБізнесІнформ. Режим доступа: http://news.liga.net/news/economics/463454-vukraine-razrabotali-transportnuyu-strategiyu-do2020-goda.htm. - Загл. с экрана.

Експерт редакційної колегії к.е.н., доцент УкрДУЗТ Шраменко О.В.

УДК 338.012

\title{
ЗАЛІЗНИЧНИЙ ТРАНСПОРТ - СКЛАДОВА МАТЕРІАЛЬНОГО ВИРОБНИЦТВА ДЕРЖАВИ
}

\author{
Рачинська А.В., аспірант (ДЕТУТ)
}

Транспортний сектор відіграє важливу роль у функиіонуванні та розвитку економіки держави, забезпечуючи зв'язок виробничтва і споживання, $\epsilon$ каталізатором активності економіки й руху товарно - матеріальних потоків, підтримує мобільність робочої сили та задовольняє потреби населення у перевезення. Досліджені теоретичні та практичні основи рівня впливу залізничного 
транспорту на транспортну систему держави. Визначені тенденції зміни показників перевезення вантажів за видами транспорту, структура перевезення та відправлення вантажів транспортною системою України.

Ключові слова: транспортна система, залізничний транспорт, перевезення вантажів, відправлення вантажів

\title{
ЖЕЛЕЗНОДОРОЖНЫЙ ТРАНСПОРТ - СОСТАВЛЯЮЩАЯ МАТЕРИАЛЬНОГО ПРОИЗВОДСТВА ГОСУДАРСТВА
}

\author{
Рачинская А.В., аспирант (ГЭТУТ)
}

\begin{abstract}
Транспортный сектор играет важную роль в функционировании и развитии экономики государства, обеспечивая связь производства и потребления, является катализатором активности экономики и движения товарно - материальных потоков, поддержсиает мобильность рабочей сильл и удовлетворяет потребности населения в перевозках. Исследованы теоретические и практические основы уровня воздействия железнодорожного транспорта на транспортную систему страны. Определены тенденции изменения показателей перевозки грузов по видам транспорта, структура перевозки и отправки грузов транспортной системой Украинь
\end{abstract}

Ключевые слова: транспортная система, жселезнодорожный транспорт, перевозки грузов, отправка грузов

\section{RAIL TRANSPORT - COMPONENT MANUFACTURING MATERIAL STATE}

\author{
Rachynska A.V., post graduate student \\ (State Economic and Technological University of Transport)
}

At present transport system of Ukraine is not fully prepared to provide transportation in the required quantities. Due to lack of regulatory framework and low investment potential of the transport system increased wear of means, deteriorating their structure is not ensured proper traffic safety, increasing the negative impact of transport on the environment and human health. All this in the global financial crisis and fierce competition leads to repression Ukrainian carriers with international transport market, reduces the quality of service of domestic enterprises and households, creating a real threat to economic security. The transport sector plays an important role in functioning and development of the state economy, providing a link production and consumption, is a catalyst activity and economy of movement commodity - of material flows, supports labor mobility and meets the needs of people in traffic. Theoretical and practical basis of the impact of rail transport in the transport system of the state. Identified trends in indicators freight modal structure of transport and shipment transport system of Ukraine

Keywords: the transport system, railways, transportation, shipment of goods

Постановка проблеми. На даний час транспортна система України не в повній мірі готова до забезпечення перевезень у необхідних обсягах. Внаслідок недостатнього розвитку нормативно-правової бази i низького інвестиційного потенціалу транспортнодорожнього комплексу збільшується зношення технічних засобів, погіршується їх структура, не забезпечується належна безпека руху, зростає негативний вплив діяльності транспорту на навколишне природне середовище та здоров'я людини. Все це в умовах світової фінансової кризи та жорсткої конкуренції призводить до витіснення українських перевізників 3 міжнародних ринків транспортних послуг, знижує якість обслуговування вітчизняних підприємств i населення, створює реальну загрозу економічній безпеці держави.

Аналіз останніх досліджень i публікацій. 3 метою покращення ситуації, що склалася в транспортній сфері, прискорення іï виходу з кризи та надання необхідного імпульсу для подальшого розвитку присвячені праці багатьох вчених-економістів залізничного транспорту: Г.Д.Ейтутіса [1], П. Корнієнко [2], О.В. Собкевича, К.М. Михайличенко [3], С.П. Лози [4] та інших.

Виділення невирішених частин загальної проблеми. Стан виробничо-технічної бази залізниць і технологічний рівень перевезень 
за багатьма параметрами не відповідає зростаючим потребам суспільства та європейським стандартам якості надання транспортних послуг. Подолання відставання у розвитку мережі українських залізниць від залізниць країн СС.

Отже, прискорення вирішення цих проблем має виключно важливе значення не тільки для транспортної галузі, а і для держави в цілому, ефективного функціонування іiі виробничої та соціальної сфер, яке значною мірою забезпечується стабільною i надійною роботою транспорту. Все більшої уваги набуває роль транспорту у розвитку зовнішньоекономічних зв'язків, реалізації геополітичного потенціалу України як транзитної держави.

Метою статті. Полягає в аналізі стану транспортної системи України і місця залізничного транспорту в ній.

\section{дослідження}

Виклад основного

Залізничний транспорт України - провідна сфера транспортної системи держави, яка має виняткове значення для функціонування національної економіки, забезпечуючи цілорічний регулярний рух, перевезення продукції промисловості та мобільність населення.

Перевагами цього виду транспорту є велика розгалуженість та відносно низькі тарифи. Важливість залізничного транспорту в системі транспортних комунікацій України посилюється і тим, що через територію держави пролягають основні транспортні транс'європейські коридори: Схід - Захід, Балтика — Чорне море.

За функціональними особливостями залізничний транспорт поділяється на вантажний та пасажирський. Це зв'язано з тим, що транспорт виступає необхідною передумовою функціонування як матеріального виробництва, так i сфери обслуговування, в тому числі пасажирських перевезень.

Пасажирський залізничний транспорт $\epsilon$ невиробничою сферою $\mathrm{i}$ належить до інфраструктурних галузей. Вантажний транспорт — сфера виробничої інфраструктури. Не виробляючи безпосередньо матеріальної продукції, вантажний транспорт $є$ четвертою складовою матеріального виробництва після видобувної, переробної промисловості і сільського господарства. Жодна з названих трьох основних складових матеріального виробництва не здатна функціонувати без транспортного забезпечення.

Важливим є південно-західний напрямок, інтенсивні вантажо- i пасажиропотоки якого пов'язані 3 перевезенням імпортно-експортних вантажів 3 України, а також вантажів 3 Росії, Білорусі у чорноморські порти і у зворотньому напрямку; пасажирів, які їдуть на відпочинок i лікування на курорти Криму, Причорномор'я та Приазов'я. У здійсненні цих зв'язків важливу роль відіграють лінії Харків - Запоріжжя Сімферополь, Харків - Кременчук - Одеса, Харків - Дніпропетровськ - Херсон.

Важливе значення для внутрішньодержавних економічних зв'язків мають напрямки Київ - Полтава - Харків, Київ Одеса, а для зовнішньоекономічних зв'язків Київ - Ковель - Хелм 3 виходом на Польщу та інші країни зарубіжної Свропи. Після створення морської паромної переправи Батумі - Одеса значно зросло значення напрямку Одеса - Львів - Перемишль, яка відтепер відіграє важливу роль у здійсненні не лише внутрішньодержавних i міждержавних зв'язків України, а й дає змогу Україні надавати транспортні послуги країнам Закавказзя для їх економічних зв'язків з країнами Європи.

В Україні транспортна галузь переживає період нестабільності і демонструє нестабільну динаміку обсягів вантажних перевезень, тому було вивчено динаміку зміни перевезення вантажів за видами транспорту в Україні, яка наведена на рис. 1

У 2013 р. підприємствами транспортної галузі було перевезено 1837 млн.т вантажів, порівняно 32012 р. загальні обсяги перевезення зменшились на 16 млн.т, або на 0,86\%. Наразі Україна досі не вийшла на докризові показники перевезень: у 2013 р. обсяги перевезень вантажів становили 92,3\% відносно рівня 2007 р. криза в економіці та складна обстановка на сходи України негативно позначились на показниках роботи транспортної галузі у 2013 р.

Залізничний транспорт був і залишається сьогодні основною ланкою у транспортному комплексі країни. В Україні електрифіковано майже 43\% від загальної довжини залізничної мережі, а виконувана робота 3 використанням електротяги становить 82,7\%, що призводить до значного зменшення собівартості перевезень електротягою, ніж за використанням теплотяги. На протязі періоду, що підлягає аналізу питома вага обсягів перевезень залізничним транспортом від загального обсягу перевезень коливалась від $15,4 \%$ (у 1995 р.) до найбільшої - 26,9\% (y 2003 p.). 


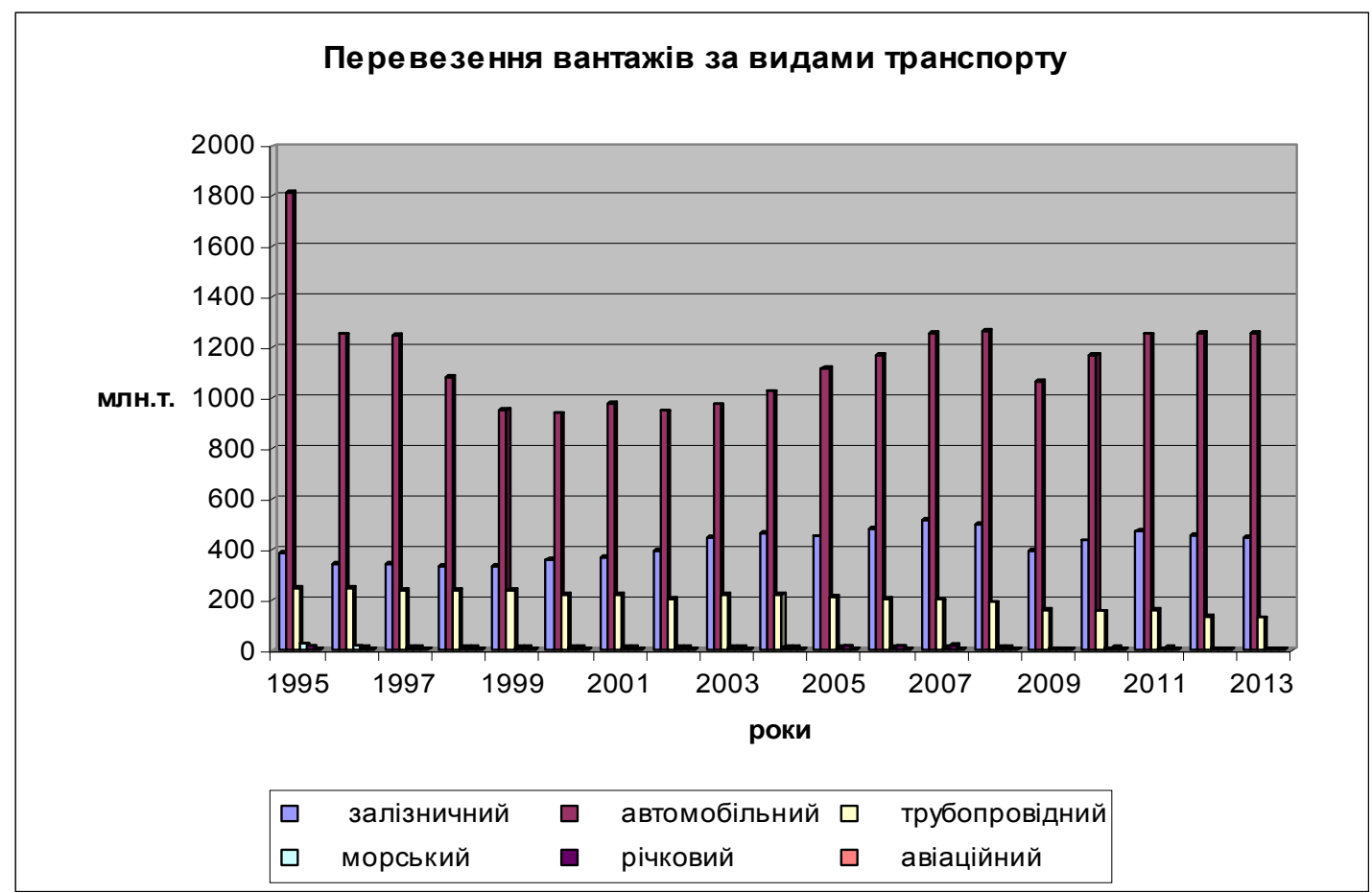

Рис 1. Динаміка перевезення вантажів за видами транспорту за період 1995-2013 рр. [10]

У 2013 p. порівняно із 2012 р. обсяг перевезень залізничним транспортом зменшився на $2,84 \%$ і становив 444 млн.т вантажів (або 86,4\% від рівня 2007 р.). Скорочення обсягів перевезень пов'язане із критичним станом інфраструктури та рухомого складу залізничного транспорту, що заважає доставляти вантажі швидко, вчасно та без втрат.

Основної причиною падіння обсягів вантажних перевезень $\epsilon$ кризовий стан економіки й насамперед промисловості, що значною мірою зумовлено бойовими діями на сході країни.

Структура перевезення вантажів за 2007 та
2013 pp. за видами транспорту наведена відповідно на рис. 2 та 3. Результати аналізу дозволили зробити наступний висновок. Оцінка перевезення вантажів за видами транспорту свідчить про позитивну тенденцію збільшення питомої ваги автомобільного транспорту в загальному обсязі перевезень по Україні з 63,1\% у 2007 р. до 68,6\% у 2013 р, темп зростання питомої ваги склав 108,7\%. Збільшення питомої ваги автомобільного транспорту відбувається за рахунок втрати позицій у транспортуванні нафтопродуктів трубопровідним транспортом.

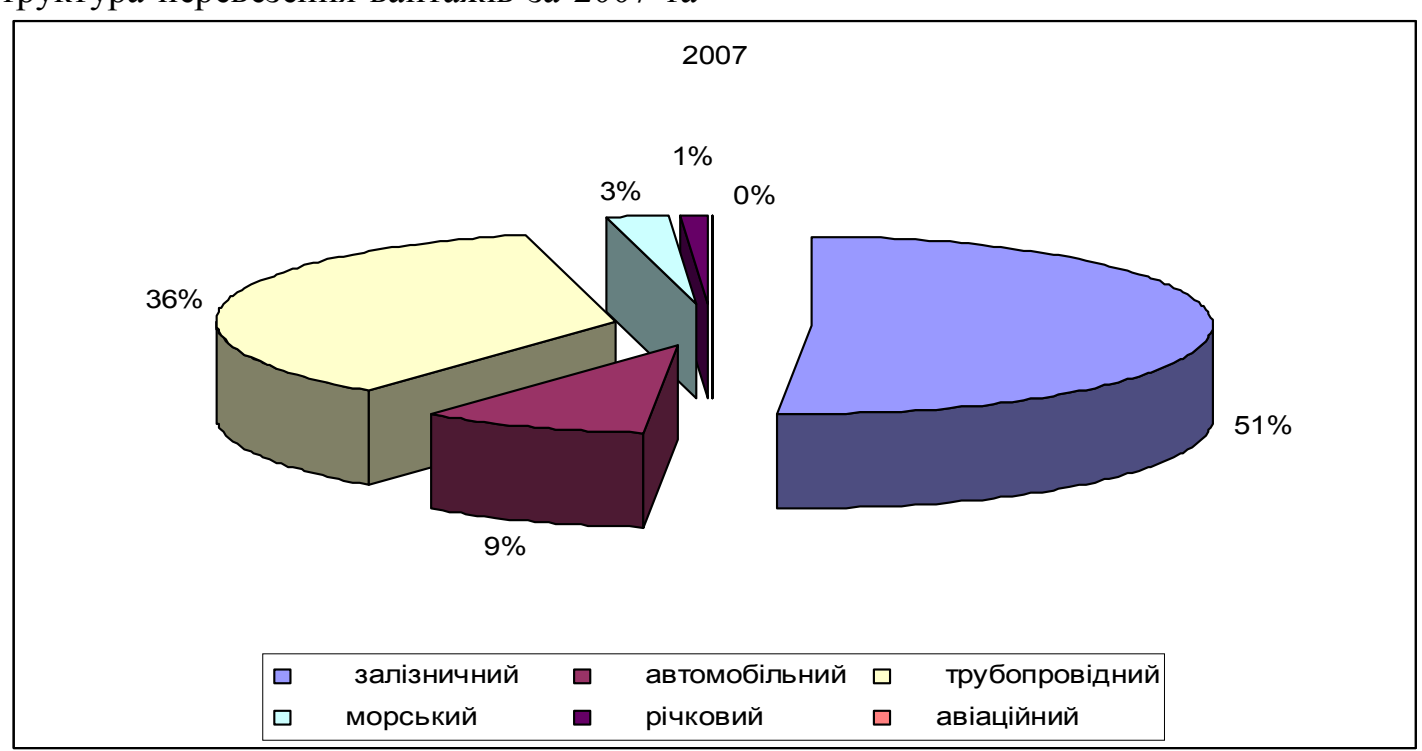

Рис 2. Структура перевезення вантажів за видами транспорту за 2007 р [10] 


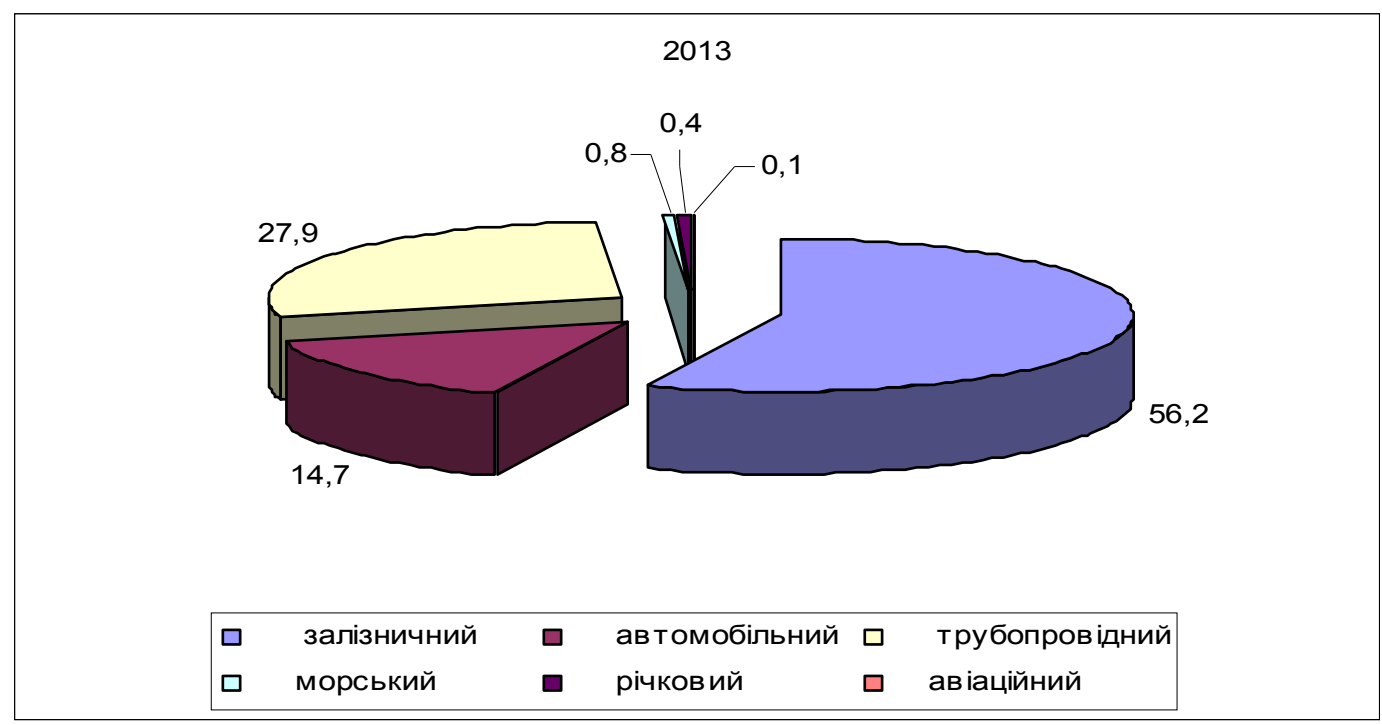

Рис. 3 Структура перевезення вантажів за видами транспорту за 2013 р. [10]

Залізничний транспорт забезпечує потреби у внутрішніх та міжнародних перевезеннях. Його питома вага в загальному вантажообігу всіх видів транспорту за 2013 р. складала $56,2 \%$, у загальному пасажирообороті - 38,2\%. В Європі українські залізниці займають провідне місце, оскільки їх вантажообіг станом на 2013 р. складав 399,6 млрд.т-км, пасажирооборот - 49 млрд.пас-км на рік.

За загальною довжиною залізничних колій Україна посідає четверте місце у світі після США, Росії та Канади. Експлуатаційна довжина колій залізниць становить 22,1 тис.км, в тому числі електрифікованих ліній майже 10 тис.км., щільність залізничної мережі - 36,6 км на 1 тис.км ${ }^{2}$ території, що є досить високим показником в світі. Через територію України проходять шість залізничних транспортних коридорів, загальною протяжністю 3162 км, що становить 14,4\% експлуатаційної довжини залізничних ліній.

Головною особливістю транспорту $є$ його специфічна роль в економіці: транспорт $є$ iї невід'ємною ланкою, що завершує процес виробництва продукції в процесі обігу, тобто від решти галузей він відрізняється тим, що $\epsilon$ «продовженням процесу виробництва в межах процесу обігу і для процесу обігу...». Транспорт забезпечує економічні взаємозв'язки між різними галузями і безперервність процесів виробництва i обігу продукції, за допомогою транспортної інфраструктури переміщається те, що було вироблене $\mathrm{i}$ буде спожито в національній економіці. Таким чином, структура й обсяги вантажних потоків, їх розподіл територією країни, за напрямками i за сезонами, визначаються не галуззю, або самими транспортними підприємствами, а підприємствами і організаціями яким належать вантажі.

Проведені дослідженні аналіз динаміки обсягів перевезень охоплює період 1995-2014 рр. та, зокрема, включає до себе співвідношення обсягових показників між залізницями України.

Аналіз динаміки відправлення вантажів показав, що залізничний транспорт нарощує обсяги перевезень. Зокрема, відправлення вантажів по Укрзалізниці починаючи з 1999 р. мали тенденцію до збільшення, крім 2005 р. коли обсяги перевезень скоротилися на $2,2 \%$ через зменшення відправлення вантажів по Донецький, Одеський та Львівський залізницях. У 2006 р. зростання обсягів перевезень було стабілізовано, а їх рівень перевищив показник 1999 р. на 40,07\%. Найбільш успішним був 2007 р., коли залізницями було відправлено найбільша кількість вантажу 415910,6 млн.т за період з 1994 р. по 2007 р., ріст до 2006 склав 4,5\%, до рівня 1999 р. - 46,3\%.

В цілому за період 1994-2013 рр. аналіз динаміки відправлення вантажів по Укрзалізниці виявив стійку тенденцію до скорочення цього показника впродовж всього періоду, за винятком незначного збільшення з 2000 по 2004 pp. та у 2006 та 2007 рр. відповідно на 4,8 та 4,5\% до попередніх років. В цілому середній рівень за період склав 350719,5 тис.т, середній темп зростання знаходиться на рівні $98,2 \%$, маючи середнє абсолютне зменшення відправлення вантажів на 3993,1 тис.т щорічно.

Перевезення вантажів іншими залізницями змінювалось несуттєво, а їх відносно невелике значення дозволило не вдаватись до детального аналізу та перейти до розгляду тенденцій зміни вантажообігу. 


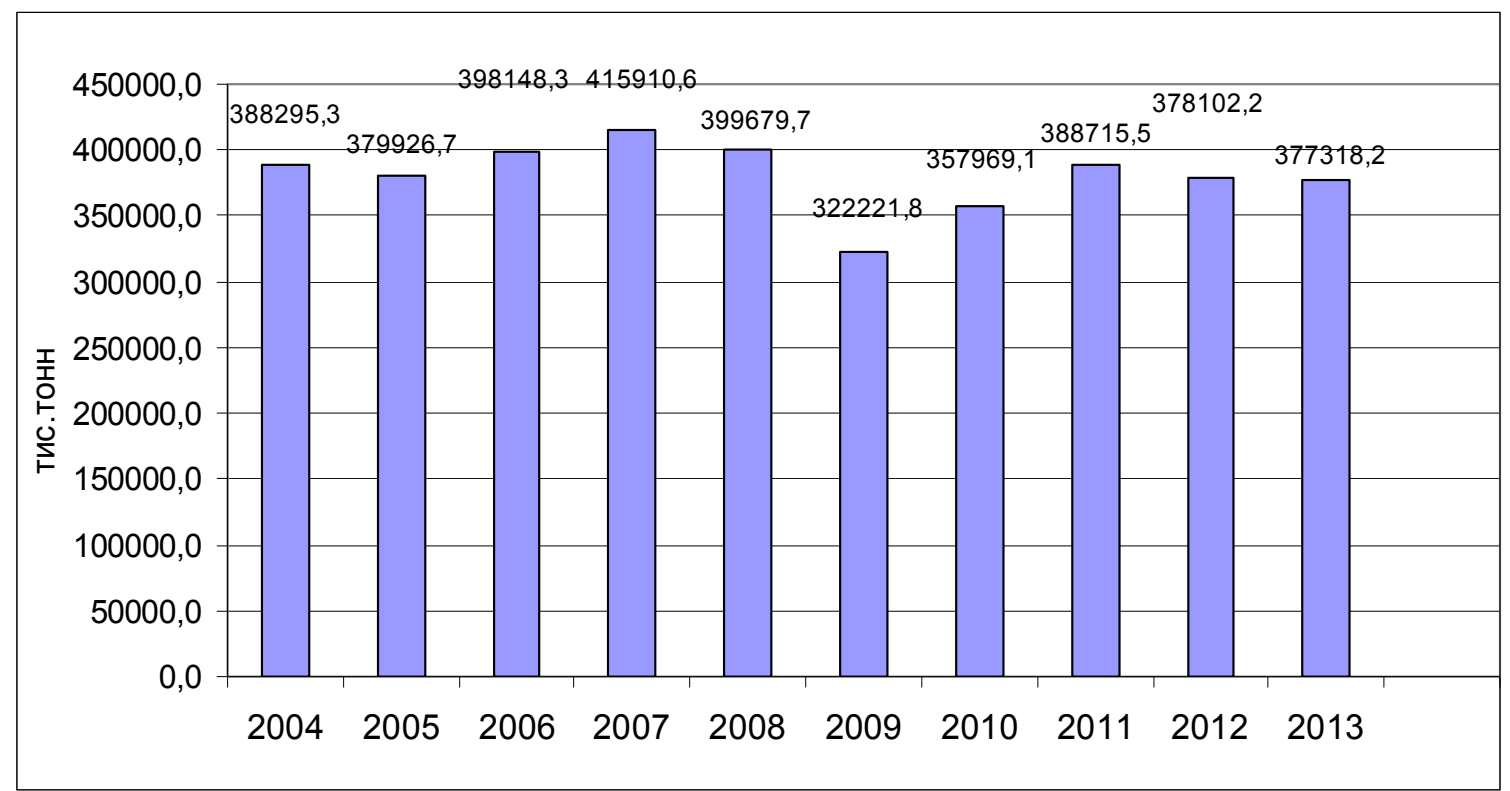

Рис. 4. Аналіз динаміки відправлення вантажів всього по Укрзалізниці за 1994-2013 рр. [9]

Аналіз динаміки відправлення вантажів не достатньо повно характеризує загальний обсяг роботи залізничного транспорту, оскільки він безпосередньо залежить не тільки від обсягів, а і від дальності перевезень.

Висновок. Враховуючи зазаначене, транспортний сектор перетворюється для держава на чинник ризику що не піддається точним прогнозам. У разі зволікання із запровадженням ефективних заходів державної політики ймовірна неспроможність залізничного транспорту забезпечити в найближчій перспективі потреби економічного зростання країни у перевезеннях, а також потреби населення у пересуванні у зв'язку із майбутнім зростанням платоспроможного попиту, розвитку бізнесу та туризму.

Отже, розвиток залізничного транспорту повинен бути політикою сталого економічного зростання замість діючої політики руйнування. Основними принципами нової політики діяльності мають стати: корпоратизація на транспорті, демонополізація, розвиток конкурентного середовища.

\section{СПИСОК ЛІТЕРАТУРИ}

1. Ейтутіс Г.Д. Реформування залізничного транспорту України - один із можливих шляхів підвищення ефективності його функціонування в сучасних економічних умовах / Г.Д. Ейтутіс //
Економіст. - 2008. - № 5. - С. 39-41.

2. Корнієнко П. Нормативно-правове регулювання залізничного транспорту в Україні (друга половина XIX століття) / П. Корніснко // Віче. - 2007. - № 16. - С. 14-15.

3. Собкевич О.В. Механізм ефективного використання та розвитку потенціалу транспортнодорожнього комплексу України. / О.В. Собкевич, К.М. Михайличенко, О.Ю. Ємельянова - К.: НІСД, 2014. - 60 c.

4. Лоза С.П. Сучасний стан i перспективи розвитку залізниць України / С. П. Лоза // Актуальні проблеми економіки. - 2006. - № 11. - С. 22 - 38.

5. Гуріна М. Транспортна система України / М. Гуріна // Вісник податкової служби України. - 2002. - № 42. - C. 46-50.

6. Давидяк Т. Залізничний транспорт; реалії та перспективи / Т.Давидяк // Голос України. - 2005. - С. 12.

7. Олійник В. Головна транспортна система України / В.Олійник // Охорона праці. - 2001. - № 8. C.13-15.

8. Чеховська М. Сутність та принципи корпоративного управління в системі залізничного транспорту України / М. Чеховська // Економіст. - 2007. № 6. - С. 66-68.

9. Официальный сайт Укрзализныци [Электронный ресурс]: Режим доступа: http://uz.gov.ua/. Назва $з$ екрана.

10. Официальный сайт Госкомстату Украины [Электронный ресурс]: Режим доступа: http://www.ukrstat.gov.ua/. Назва з екрана.

Рецензент д.е.н., професор ДЕТУТ Ейтутіс Г.Д. Експерт редакційної колегії к.е.н., дочент УкрДУЗТ Зубенко В.О. 